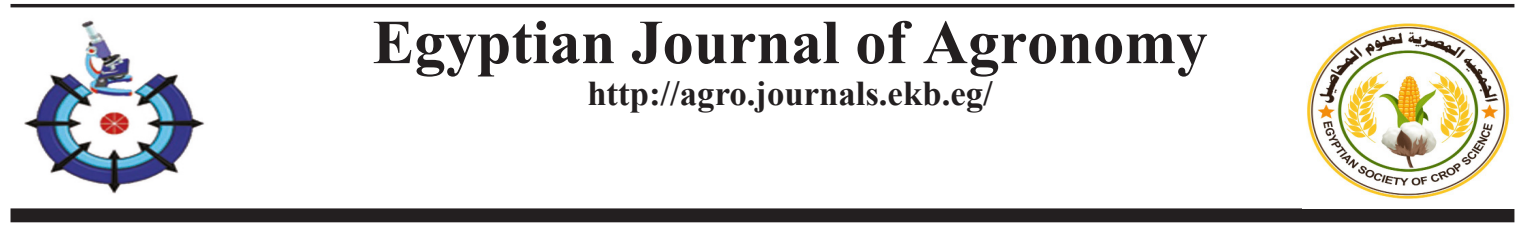

\title{
Influence of Hydrogen Peroxide and Nanofertilizer on Rusts Development and Wheat Productivity
}

\author{
Lamyaa A. Abd El-Rahman(1), Reda I. Omara(2), Mohamed A. Gad ${ }^{(2)}$ \# \\ ${ }^{(1)}$ Soil, Water and Environment Research Institute, Agricultural Research Center, \\ Giza, Egypt; (2) Wheat Diseases Research Department, Plant Pathology Research \\ Institute, Agricultural Research Center, Giza, Egypt.
}

\begin{abstract}
A N EXPERIMENT was conducted to study the effect of some foliar spray treatments on yellow rust and leaf rust severities, productivity, and grain quality of wheat cultivar "Gemmiza-7". The treatments: hydrogen peroxide $\left(\mathrm{H}_{2} \mathrm{O}_{2}\right) 30 \%(1 \mathrm{mM})$, nano $\mathrm{CaCO}_{3} 0.5 \%$ (5.0g/L), combination of $\mathrm{H}_{2} \mathrm{O}_{2} 30 \%(1.0 \mathrm{mM})$, and nano $\mathrm{CaCO}_{3} 0.5 \%(5.0 \mathrm{~g} / \mathrm{L}), \mathrm{KCl}(5.0 \mathrm{~g} / \mathrm{L})$ and fungicide Tilt $25 \%$ EC (Propiconazole) at $25 \mathrm{~mL} / 100$ liter- were applied with the control treatment (spraying with water). Results indicated that, all treatments had a significant effect on all the studied parameters, hence reduced rust disease infection and increased 1000 kernel weight, grain, straw, and biological yield of wheat, mineral uptake by wheat plants and total protein in grains compared with the untreated control. Spraying with the fungicide recorded the most effective treatment in reducing the yellow and leaf rusts severity in both seasons, followed by spraying with $\mathrm{H}_{2} \mathrm{O}_{2} 30 \%$ which gave a disease control of (55.00 and 54.54\%) for yellow rust and $(74.08$ and $70.57 \%)$ for leaf rust in the $1^{\text {st }}$ and $2^{\text {nd }}$ seasons, respectively. Spraying plants with $\mathrm{H}_{2} \mathrm{O}_{2} 30 \%+$ nano $\mathrm{CaCO}_{3} 0.5 \%$ after 70 and 100 days from sowing recorded the tallest plants and maximum values of shoot dry weight/plant, root dry weight/plant and flag leaf area. Significant increase in the concentrations of chlorophyll a, b and total chlorophyll in leaf tissues was observed. Increase in mineral contents and uptake by wheat plants without significant differences with nano $\mathrm{CaCO}_{3}$ at $0.5 \%$ and $\mathrm{KCl}$ at $0.5 \%$ was also recorded.
\end{abstract}

Keywords: Biochemical analysis, Nano particles, Rusts, Wheat, Yield.

\section{Introduction}

Wheat (Triticum aestivum L.) is the most strategic cereal crop allover the world and Egypt. Egypt faces food shortage problems because of increment of population. Therefore, Egypt is considered one of the biggest importers of wheat all over the world. Great efforts are continually driven for increasing its productivity by means of horizontal and/or vertical planting to reduce hiatus between production and consumption.

Wheat production is affected by various biotic and abiotic agents. Among the biotic agents, yellow or stripe rust caused by Puccinia striiformis f. sp. tritici, and leaf rust caused by Puccinia triticina $\mathrm{f}$. sp. tritici, that cause severe losses in grain yield because their wide distribution, their capacity to form new strains and their capability to disseminate to long locations (Soliman et al., 2012; Hasan et al., 2016; Gebril et al., 2018a, b; El-Orabey et al., 2019; Gad et al., 2019a, b; Gebrel et al., 2019; El-Naggar et al., 2020; El-Orabey et al., 2020; Gad et al., 2020; Gebrel et al., 2020). Moreover, the highly rust severity was noticed with using of nitrate- N, while decreases were noted with ammonium-N, whilst both nitrogen forms would have been prospective to increase wheat canopy size. This suggests that nitrogen impact on stripe rust that cause changes in the leaf as a substrate for pathogen growth, such as available leaf- $\mathrm{N}$ in the apoplast. Also nitrogen concentration in leaf is

\#Corresponding author email: mohamedabo2002@yahoo.com

Received 26/7/2021; Accepted 07/9/2021

DOI: 10.21608 /agro.2021.87731.1271

C2021 National Information and Documentation Center (NIDOC) 
noted to be more important for disease progress than wheat canopy size (Neumann et al., 2004).

Accordingly, the use of fungicides is an integral component of plant disease control as well as crop management but should be safety to humans and the environment (Chen, 2005). Nanotechnology at that time was the most modern field in nanotechnology in the twenty-one-century, nanotechnology such as calcium carbonate (nano$\mathrm{CaCO}_{3}$ ), using nano-scale particles is set to play an important role in the development of improved systems to increase crops's nutrient capacity. Farooqut et al. (2016) found that using nanofertilizers instead of common fertilizers may have valuable properties for crops that release nutrient requirements and discharging chemical fertilizers in a controlled manner that standardizes plant growth and improves target activity. Nano- $\mathrm{CaCO}_{3}$ is a natural $\mathrm{CO}_{2}$ foliar fertilizer obtained from limestone deposits by tribodynamic activation and micronization to levels of (10-20 microns). Kumar (2011) reported that the most of nano particles stay as thin layer on the leave surface and penetrate frequently when they get wet by dew at night. Numerous studies demonstrated that high atmospheric $\mathrm{CO}_{2}$ leads to increases in photosynthetic rate and decreases in transpiration rate of many $\mathrm{C}_{3}$-plants such as wheat, furthermore, nanoparticles enhance plant growth, yield, and grain quality (Gomaa et al., 2018).

Hydrogen peroxide is a signaling molecule in plants. $\mathrm{H}_{2} \mathrm{O}_{2}$, is moderately reactive and has relatively long half-life, it is well known that excess of $\mathrm{H}_{2} \mathrm{O}_{2}$ in plant cells lead to the appearance of oxidative stress. It established and well known that $\mathrm{H}_{2} \mathrm{O}_{2}$ has two somewhat opposing roles in plant. A wide generated stable reactive oxygen species is the Hydrogen peroxide $\left(\mathrm{H}_{2} \mathrm{O}_{2}\right)$, is considered as a significant signaling molecule that mediates different physiological and biochemical processes in plants, where $\mathrm{H}_{2} \mathrm{O}_{2}$ application acts as a second messenger in response to different stresses (Omara \& Abdelaal, 2018). Also, $\mathrm{H}_{2} \mathrm{O}_{2}$ considered as a key regulator in different physiological processes. Wang et al. (2012) found that $\mathrm{H}_{2} \mathrm{O}_{2}$ involved in the acclimation and tolerance of plants grown under stress. Exogenous application of $\mathrm{H}_{2} \mathrm{O}_{2}$ at low concentrations $(\leq 2.5 \mathrm{mM})$ had stimulatory effect on growth traits of plants, while the concentration up to $5.0 \mathrm{mM}$ played an opposite role (Deng et al., 2012). Therefore, $\mathrm{H}_{2} \mathrm{O}_{2}$, at low concentrations, is considered one of the exogenous materials that used to induce the defense mechanisms in plant cells. In this concern, many authors reported that spraying plants with low concentration of $\mathrm{H}_{2} \mathrm{O}_{2}$ significantly enhanced growth and productivity and mineral uptake than untreated plants (Ishibashi et al., 2021).

Potassium plays a vital role in improving the plant tolerance to stress conditions. Several physiological processes as activation of enzymes, translocation of photosynthates, photosynthesis, maintenance of turgescence, $\mathrm{K}$ is an essential element (Mengel \& Kirkby, 2001). An appropriate supply of potassium fertilizers is essential for sustainable crop production. Plants uptake the potassium originally from the soil in the form of $\mathrm{K}^{+}$, which is strongly absorbed via soil components. Especially by clay particles, and thus they do not move easily in the soil. However potassium content in soil has traditionally been considered appropriate for normal plant growth, awareness has grown regarding the importance of potassium in crop production (Rahman et al., 2014). Under continuous cropping, cultivars responsive to fertilizers with improved management practices lead to $\mathrm{K}$ mining. In this regard, Rahman et al. (2014) and Adhikari et al. (2020) reported that significant increases in growth, chlorophyll content, productivity, as well as N, P and K uptake by straw and grains by spraying potassium chloride than unsprayed plants.

Therefore, this study was conducted to investigate the potential role of some environment friendly treatments including a signaling molecule, $\mathrm{H}_{2} \mathrm{O}_{2}$, nano $\mathrm{CaCO}_{3}$ fertilizer, $\mathrm{KCl}$, all compared with Tilt 25\% (fungicide) to control rust pathogens and to improve the performance of growth, productivity and grain quality of wheat cultivar "Gemmiza-7"under open field conditions.

\section{Materials and Methods}

The experiments were carried out at ElGemmeiza Agriculture Research Station, ElGharbiya Governorate, Egypt to study the effect of foliar spraying treatments on wheat yellow rust and leaf rust severities, productivity, and grain quality of wheat cultivar 'Gemmiza-7', during $2019 / 2020$ and 2020/2021 growing seasons. Composite soil samples were obtained from the experimental site before sowing and different physical and chemical properties were determined using standard procedures as presented in Table 1 . 
TABLE 1. Physical and chemical properties of the soil during 2019/2020 and 2020/2021 growing seasons

\begin{tabular}{lccccc}
\hline Soil texture & $\begin{array}{c}\text { Ec } \\
\mathbf{d S m}^{-\mathbf{1}}\end{array}$ & $\begin{array}{c}\text { PH } \\
(\mathbf{1 : 2 . 5})\end{array}$ & $\begin{array}{c}\text { Available } \mathbf{N} \\
(\mathbf{p p m})\end{array}$ & $\begin{array}{c}\text { Available } \mathbf{P} \\
(\mathbf{p p m})\end{array}$ & $\begin{array}{c}\text { Available K } \\
(\mathbf{p p m})\end{array}$ \\
\hline Clayey & 2.14 & 7.88 & 30 & 7.14 & 310
\end{tabular}

Cultivation of the susceptible wheat cultivar

The wheat seeds (Gemmiza-7 cultivar) were sown on November $24^{\text {th }}$ and $26^{\text {th }}$ during $2019 / 2020$ and 2020/2021, respectively. The plot area was $10.5 \mathrm{~m}^{2}(3.5 \mathrm{~m}$ long, $3 \mathrm{~m}$ wide) and $20 \mathrm{~cm}$ apart. Seeds were sown at a rat of $60 \mathrm{~kg} / \mathrm{fed}$. The susceptible variety: Morocco was sown as a rust spreader. The spreader was artificially inoculated using a mixture of yellow and leaf rust races (Obtained from Wheat Diseases Res. Depart., Plant Pathol. Res. Institute, ARC. Egypt) (Tervet \& Cassel, 1951).

\section{Treatment preparation}

Five foliar treatments were used as a following: $\mathrm{H}_{2} \mathrm{O}_{2} 30 \%$ (1.0mM), nano $\mathrm{CaCO}_{3}$ 0.5\% (5.0g/L), combination of $\mathrm{H}_{2} \mathrm{O}_{2} 30 \%(1.0 \mathrm{mM})$ with nano $\mathrm{CaCO}_{3} 0.5 \%(5.0 \mathrm{~g} / \mathrm{L}), \mathrm{KCl}(5.0 \mathrm{~g} / \mathrm{L})$, and fungicide Tilt 25\% EC (Propiconazole) at $25 \mathrm{~mL} / 100$ liter compared to control treatment (spraying with water). The design of this experiment was randomized complete block design (RCBD) with three replicates.

Nano- $\mathrm{CaCO}_{3}$ fertilizer consists of 77.9 calcium carbonate, 8.7 magnesium carbonate, 7.47 silica, 0.74 iron 0.2 potassium, 0.03 sodium, $0.02 \%$ phosphate and trace amount of alumina, sulphate, strontium, barium, manganese, and zinc. Also, nitrogen fertilizer was applied at $75 \mathrm{~kg} /$ feddan as urea $(46 \% \mathrm{~N})$ and phosphorus fertilizer was applied at $15 \mathrm{~kg} \mathrm{P}_{2} \mathrm{O}_{5}$ as monosuper phosphate $\left(15 \% \mathrm{P}_{2} \mathrm{O}_{5}\right)$ and $24 \mathrm{~kg} \mathrm{~K}_{2} \mathrm{O} / \mathrm{fed}$. as potassium sulphate $(48 \%$ $\mathrm{K}_{2} \mathrm{O}$ ). Whole of the phosphorus and one-third of the nitrogen was applied as basal dose. Remaining nitrogen and potassium were applied with first and second irrigation in equal splits. In addition to soaking irrigation other four irrigations were given during the whole growing season.

These treatments were sprayed twice after 70 and 100 days from sowing and using spreading agent to improve adherence of the spray to the plant foliage for rising absorption of solutions by wheat plants. The untreated control was sprayed with only water. One meter space was left between each two experimental plots without spraying as a guard to avert the overlapping of spraying solutions.
Disease assessment

When the spreader of wheat plants were $50 \%$ infected, disease severity (DS\%) was recorded four times, every seven days interval, during $2019 / 2020$ and 2020/2021 growing seasons, expressed as percentage coverage of leaves with rust pustules according to Peterson et al. (1948).

\section{Plant growth}

At 130 days after sowing 20 plants at random were taken from each plot to detect plant height $(\mathrm{cm})$, root dry weight/plant $(\mathrm{g})$, shoot dry weight (g), flag leaf area $\left(\mathrm{cm}^{2}\right)$.

\section{Biochemical traits \\ Leaf pigments}

A disc sample from the fresh flag leaves of wheat plant was randomly taken from every experimental unit at 130 days after transplanting in both growing seasons to determine chlorophyll $\mathrm{a}, \mathrm{b}$ and chlorophyll $(\mathrm{a}+\mathrm{b})$ as well as carotenoids according to the method adopted by Wettestein (1957). The concentration of $\mathrm{H}_{2} \mathrm{O}_{2}$ in leaves was determined according to Velikova et al. (2000).

\section{Yield components}

At harvest, the guarded plants of one inner meter square were taken from each plot to determine grain yield (ton/fed.), straw yield (ton/ fed.) and biological yield (ton/fed) was estimated from each plot, also 1000-grain weight (g) was recorded.

\section{Mineral content and uptake}

Straw and grain samples of each treatment were oven dried at $70^{\circ} \mathrm{C}$ to become constant weight, and this weight was recorded and kept for chemical analysis. Nitrogen $(\mathrm{N}), \mathrm{P}$ and $\mathrm{K}$ concentration as percentages in straw and grains were determined according to the methods described by Page (1982). Nitrogen (N), P and K -uptakes $\mathrm{kg} / \mathrm{fed}$. were determined by multiplying the values of $\{(\mathrm{N}, \mathrm{P}$ and $\mathrm{K} \% \mathrm{x}$ Yield $\mathrm{kg} / \mathrm{fed}) /$. $100\}$ in grains and straw according to A.O.A.C. (2000). Calcium (Ca ppm) of both wheat grain and straw were determined according to Cheng \& Bray (1953). Total proteins in grains were calculated by multiplying N\% $\times 5.70$ (Bishni \& Hughes, 1979). 
Statistical analysis

Statistical analysis was conducted for all collected data by analysis of variance (ANOVA) using software package SPSS22.

\section{Results and Discussion}

Effect of treatments on yellow rust and leaf rust severities (\%)

Foliar spray of wheat cultivar; Gemmiza-7 with some treatments at 70 and 100 days after sowing decreased yellow rust and leaf rust severities (\%) in both seasons compared to control treatment (spraying with water) as shown in Table 2 and Fig. 1. Spraying with the fungicide Tilt significantly decreased rust severity of yellow and leaf rust percentages, where recorded the highest yellow and leaf rusts control in both seasons. Those results agreed with Ransom \& McMullen (2008). They found that spraying wheat plants with Tilt 25\% EC as fungicide was the best for controlling wheat yellow rust. Also Gad et al. (2020) revealed that minimum yellow rust disease severity of $1.67 \%$ and disease control of $98.07 \%$ was recorded with Tilt 25\% EC.

The second treatment of $\mathrm{H}_{2} \mathrm{O}_{2} 30 \%$ at $1 \mathrm{mM}$ was recorded (16.67 and $18.67 \%)$ and (23.33 and $26.13 \%$ ) for disease severity (\%) of yellow and leaf rusts during 2019/2020 and 2020/2021 growing seasons, respectively and it was recorded (55.00 and $54.54 \%$ ) and (74.08 and 70.57\%) for yellow and leaf rusts control in the $1^{\text {st }}$ and $2^{\text {nd }}$ seasons, respectively. Then, spraying with a mixture of $\mathrm{H}_{2} \mathrm{O}_{2} 30 \%$ at $1 \mathrm{mM}+$ nano $\mathrm{CaCO}_{3}$ at $0.5 \%$ came in the third rank and recorded (20.00 and 22.40\%) for yellow rust and (30.00 and 30.60\%) for leaf rust in the $1^{\text {st }}$ and $2^{\text {nd }}$ seasons, respectively, while spraying with water recorded (36.67 and 41.07\%) for yellow rust and (90.00 and $88.80 \%$ ) for leaf rust in the $1^{\text {st }}$ and $2^{\text {nd }}$ seasons, respectively. Therefore, $\mathrm{H}_{2} \mathrm{O}_{2}$ at low concentrations is considered one of the exogenous materials that used to induce the defense mechanisms in plant cells. Also, $\mathrm{H}_{2} \mathrm{O}_{2}$ is found to be involved in the acclimation and tolerance of plants grown under stress (Wang et al., 2012). Generally, the level of disease severity was far higher in the unsprayed plots compared to sprayed ones.

Effect of treatments on plant growth parameters

Data in Table 3 show that, foliar spraying with some treatments at 70 and 100 days after sowing increased plant height, root dry weight/plant, shoot dry weight and flag leaf area of wheat plants (Gemmeiza-7) compared to control treatment (spraying with water). Spraying with a mixture of $\mathrm{H}_{2} \mathrm{O}_{2} 30 \%$ at $1 \mathrm{mM}+$ nano $\mathrm{CaCO}_{3}$ at $0.5 \%$ recorded the tallest plants and maximum values of root dry weight/plant, shoot dry weight/plant and flag leaf area, followed by spraying with nano $\mathrm{CaCO}_{3}$ at $0.5 \%$ in both growing seasons compared to other spraying treatments.

The increasing of plant growth recorded with nano $\mathrm{CaCO}_{3}$, due to its role as a long-term reservoir providing plants with $\mathrm{CO}_{2}$ (Kumar, 2011). Hence, it can promote growth and productivity, as higher $\mathrm{CO}_{2}$ concentrations increase the carbon uptake, biomass and leaf area of plants. Nano $\mathrm{CaCO}_{3}$ particles are known to remain as a thin layer on the surface of the leaves and repeatedly penetrate when they are soon wet with dew at night (Rebbeck \& Scherzer, 2002).

TABLE 2. Effect of treatments on wheat yellow rust and leaf rust severities (\%) during 2019/2020 and 2020/2021 growing seasons

\begin{tabular}{|c|c|c|c|c|c|c|c|c|}
\hline \multirow{3}{*}{ Treatment } & \multicolumn{4}{|c|}{ Yellow rust } & \multicolumn{4}{|c|}{ Leaf rust } \\
\hline & \multicolumn{2}{|c|}{$\begin{array}{c}\text { Disease severity } \\
(\%)\end{array}$} & \multicolumn{2}{|c|}{$\begin{array}{c}\text { Disease control } \\
(\%)\end{array}$} & \multicolumn{2}{|c|}{$\begin{array}{c}\text { Disease severity } \\
(\%)\end{array}$} & \multicolumn{2}{|c|}{$\begin{array}{c}\text { Disease control } \\
(\%)\end{array}$} \\
\hline & $\begin{array}{c}1^{\text {st }} \\
\text { season }\end{array}$ & $\begin{array}{c}2^{\text {nd }} \\
\text { season }\end{array}$ & $\begin{array}{c}1^{\text {st }} \\
\text { season }\end{array}$ & $\begin{array}{c}2^{\text {nd }} \\
\text { season }\end{array}$ & $\begin{array}{c}1^{\text {st }} \\
\text { season }\end{array}$ & $\begin{array}{c}2^{\text {nd }} \\
\text { season }\end{array}$ & $\begin{array}{c}1^{\text {st }} \\
\text { season }\end{array}$ & $\begin{array}{c}2^{\text {nd }} \\
\text { season }\end{array}$ \\
\hline Control (spraying with water) & $36.67 \mathrm{a}$ & $41.07 \mathrm{a}$ & 0.00 & 0.00 & $90.00 \mathrm{a}$ & $88.80 \mathrm{a}$ & 0.00 & 0.00 \\
\hline $\mathrm{H}_{2} \mathrm{O}_{2} 30 \%$ at $(1 \mathrm{mM})$ & $16.67 \mathrm{e}$ & $18.67 \mathrm{~d}$ & 55.00 & 54.54 & $23.33 \mathrm{e}$ & $26.13 \mathrm{e}$ & 74.08 & 70.57 \\
\hline Nano $\mathrm{CaCO}_{3}$ at $0.5 \%$ & $30.00 \mathrm{~b}$ & $26.60 \mathrm{~b}$ & 18.20 & 35.23 & $46.67 b$ & $49.27 b$ & 48.14 & 44.51 \\
\hline $\mathrm{H}_{2} \mathrm{O}_{2} 30 \%$ at $(1 \mathrm{mM})+$ nano $\mathrm{CaCO}_{3}$ at $0.5 \%$ & $20.00 \mathrm{~d}$ & $22.40 \mathrm{c}$ & 45.50 & 45.45 & $30.00 \mathrm{~d}$ & $30.60 \mathrm{~d}$ & 66.67 & 65.54 \\
\hline $\mathrm{KCl}$ at $0.5 \%$ & $26.67 \mathrm{c}$ & $24.87 b$ & 27.30 & 39.44 & $36.67 \mathrm{c}$ & $38.07 \mathrm{c}$ & 59.26 & 57.12 \\
\hline Fungicide Tilt $25 \%$ EC at $25 \mathrm{~mL} / 100$ liter & $1.77 \mathrm{f}$ & $1.70 \mathrm{e}$ & 95.17 & 95.86 & $0.00 \mathrm{f}$ & $0.00 \mathrm{f}$ & 100.00 & 100.00 \\
\hline LSD $_{0.05}$ & 1.48 & 1.78 & --- & --- & 2.47 & 3.17 & --- & --- \\
\hline
\end{tabular}

$1^{\text {st }}$ season $=2019 / 2020,2^{\text {nd }}$ season $=2020 / 2021$ season

Egypt. J. Agron. 43, No. 2 (2021) 


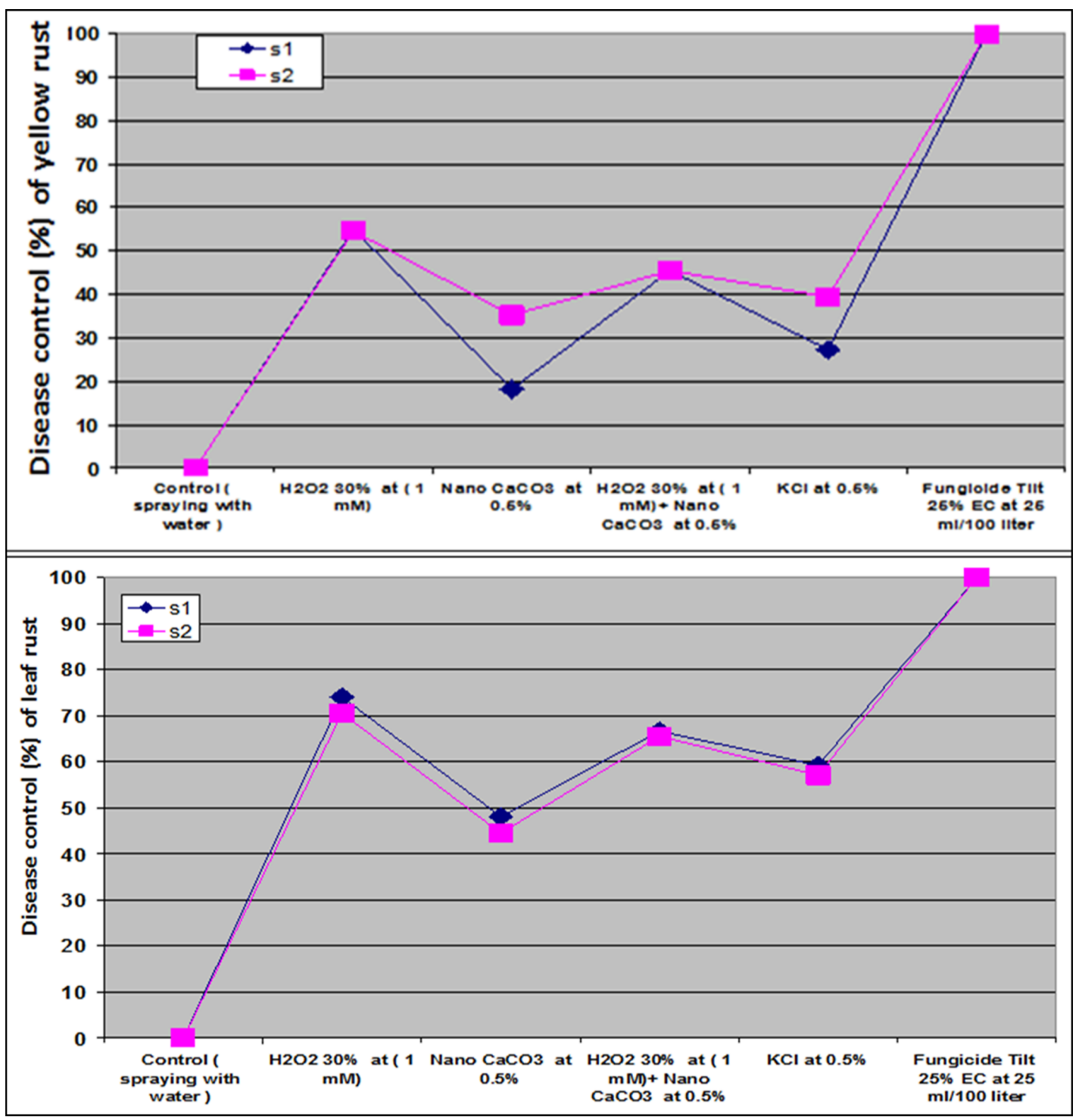

Fig. 1. Effect of treatments on wheat yellow rust and leaf rust severities (\%) during 2019/2020 and 2020/2021 growing seasons $[S 1=2019 / 2020$ season, $S 2=2020 / 2021$ season]

TABLE 3. Effect of treatments on wheat plant growth parameters during 2019/2020 and 2020/2021 growing seasons

\begin{tabular}{|c|c|c|c|c|c|c|c|c|}
\hline \multirow{2}{*}{ Treatment } & \multicolumn{2}{|c|}{$\begin{array}{l}\text { Plant height } \\
\text { (cm) }\end{array}$} & \multicolumn{2}{|c|}{$\begin{array}{l}\text { Root dry weight/ } \\
\text { plant (g) }\end{array}$} & \multicolumn{2}{|c|}{$\begin{array}{c}\text { Shoot dry } \\
\text { weight/plant (g) }\end{array}$} & \multicolumn{2}{|c|}{$\begin{array}{c}\text { Flag leaf area } \\
\left(\mathrm{cm}^{2}\right)\end{array}$} \\
\hline & $\begin{array}{c}1^{\text {st }} \\
\text { season }\end{array}$ & $\begin{array}{c}2^{\text {nd }} \\
\text { season }\end{array}$ & $\begin{array}{c}1^{\text {st }} \\
\text { season }\end{array}$ & $\begin{array}{c}2^{\text {nd }} \\
\text { season }\end{array}$ & $\begin{array}{c}1^{\text {st }} \\
\text { season }\end{array}$ & $\begin{array}{c}2^{\text {nd }} \\
\text { season }\end{array}$ & $\begin{array}{c}1^{\text {st }} \\
\text { season }\end{array}$ & $\begin{array}{c}2^{\text {nd }} \\
\text { season }\end{array}$ \\
\hline Control (spraying with water) & $92.02 \mathrm{e}$ & $94.46 \mathrm{e}$ & $0.62 b$ & $0.60 \mathrm{c}$ & $6.26 \mathrm{c}$ & $6.11 \mathrm{c}$ & $19.78 \mathrm{~d}$ & $19.16 \mathrm{~d}$ \\
\hline $\mathrm{H}_{2} \mathrm{O}_{2} 30 \%$ at $(1 \mathrm{mM})$ & $96.85 \mathrm{~d}$ & $103.63 d$ & $0.68 b$ & $0.73 b$ & $7.48 b$ & $8.00 \mathrm{~b}$ & $21.44 \mathrm{c}$ & $22.94 \mathrm{c}$ \\
\hline Nano $\mathrm{CaCO}_{3}$ at $0.5 \%$ & $106.28 \mathrm{ab}$ & $113.86 \mathrm{a}$ & $0.72 b$ & $0.77 \mathrm{~b}$ & $7.92 b$ & $8.47 b$ & $23.76 b$ & $25.42 b$ \\
\hline $\mathrm{H}_{2} \mathrm{O}_{2} 30 \%$ at $(1 \mathrm{mM})+$ nano $\mathrm{CaCO}_{3}$ at $0.5 \%$ & o $109.40 \mathrm{a}$ & $115.06 \mathrm{a}$ & $0.84 \mathrm{a}$ & $0.87 \mathrm{a}$ & $9.24 \mathrm{a}$ & $9.89 \mathrm{a}$ & $27.72 \mathrm{a}$ & $28.66 \mathrm{a}$ \\
\hline $\mathrm{KCl}$ at $0.5 \%$ & $103.13 \mathrm{bc}$ & $110.35 b$ & $0.70 \mathrm{~b}$ & $0.75 b$ & $7.70 b$ & $8.24 b$ & $23.10 \mathrm{~b}$ & $24.72 b$ \\
\hline Fungicide Tilt $25 \% \mathrm{EC}$ at $25 \mathrm{~mL} / 100$ liter & $100.83 \mathrm{~cd}$ & $107.89 \mathrm{c}$ & $0.69 \mathrm{~b}$ & $0.74 \mathrm{~b}$ & $7.59 b$ & $8.12 b$ & $22.77 b$ & $24.36 \mathrm{bc}$ \\
\hline $\mathbf{L S D}_{0.05}$ & 4.61 & 2.27 & 0.10 & 0.05 & 0.92 & 0.83 & 1.06 & 1.60 \\
\hline
\end{tabular}

$1^{\text {st }}$ season $=2019 / 2020,2^{\text {nd }}$ season $=2020 / 2021$ season 
These results are in agreement with those obtained by Gomaa et al. (2018) on wheat concerning the effect of nanoparticles. Also, Mogazy et al. (2020) who mentioned that spraying plants with $\mathrm{H}_{2} \mathrm{O}_{2}$ gave the maximum values of plant height root and shoot dry weight than unsprayed plants. Adhikari et al. (2020) noticed that spraying of soybean plants with $\mathrm{KCl}$ at $2.5 \%$ significantly increased plant height, dry weight of roots and shoots than unsprayed plants.

Effect of treatments on biochemical analysis

Data in Table 4 indicate that, all spraying treatments had a significant effect on leaf pigments than control treatment in both seasons. Spraying with nano $\mathrm{CaCO}_{3}$ at $0.5 \%$ significantly increased the concentrations of chlorophyll a, b and total chlorophyll in leaf tissues of wheat with no significant differences with spraying the mixture of $\mathrm{H}_{2} \mathrm{O}_{2} 30 \%$ at $1 \mathrm{mM}+$ nano $\mathrm{CaCO}_{3}$ at $0.5 \%$, whereas spraying with fungicide Tilt significantly increased the concentration of carotenoids in leaf tissues in both seasons. As for, $\mathrm{H}_{2} \mathrm{O}_{2}$ contents, spraying with the same treatment decreased $\mathrm{H}_{2} \mathrm{O}_{2}$ in wheat tissues compared to control (spraying with water).

The increases in total chlorophyll in leaf tissues of wheat were about 48.4 and $52.0 \%$ for spraying with the mixture of $\mathrm{H}_{2} \mathrm{O}_{2} 30 \%$ at $1 \mathrm{mM}+$ nano $\mathrm{CaCO}_{3}$ at $0.5 \%, 38.5$ and $42.1 \%$ for spraying with nano $\mathrm{CaCO}_{3}$ at $0.5 \%$ over control in the $1^{\text {st }}$ and $2^{\text {nd }}$ seasons, respectively. Mogazy et al. (2020) also explained that spraying lupine plants with hydrogen peroxide at $0.5 \%$ significantly enhanced total chlorophyll than unsprayed plants. As well as, Ishibashi et al. (2021) established that, spraying of soybean plants with $\mathrm{H}_{2} \mathrm{O}_{2}$ gave the highest leaf pigments than sprayed with distilled water.

\section{Effect of treatments on yield components}

Foliar spray of plants with the selected treatments significantly increased yield components compared to control treatment in both seasons (Table 5). Spraying with $\mathrm{H}_{2} \mathrm{O}_{2} 30 \%$ at $1 \mathrm{mM}+$ nano $\mathrm{CaCO}_{3}$ at $0.5 \%$ significantly increased 1000 kernel weight, grain yield, straw yield and biological yield of wheat, followed by spraying with nano $\mathrm{CaCO}_{3}$ at $0.5 \%$ in both seasons. The increment in grain yield of wheat were about 46.17 and $45.44 \%$ for spraying with the mixture of $\mathrm{H}_{2} \mathrm{O}_{2} 30 \%$ at $1 \mathrm{mM}+$ nano $\mathrm{CaCO}_{3}$ at $0.5 \%, 38.09$ and $43.26 \%$ for spraying with nano $\mathrm{CaCO}_{3}$ at $0.5 \%$ over control treatment during 2019/2020 and 2020/2021 growing seasons, respectively.

TABLE 4. Effect of treatments on biochemical analysis of wheat during 2019/2020 and 2020/2021 growing seasons

\begin{tabular}{|c|c|c|c|c|c|c|c|c|c|c|}
\hline \multirow{2}{*}{ Treatment } & \multicolumn{2}{|c|}{$\begin{array}{l}\text { Chlorophyll a } \\
\text { ( mg/g FW) }\end{array}$} & \multicolumn{2}{|c|}{$\begin{array}{l}\text { Chlorophyll b } \\
\text { ( mg/g FW) }\end{array}$} & \multicolumn{2}{|c|}{$\begin{array}{l}\text { Total chlorophyll } \\
\qquad(\mathrm{mg} / \mathrm{g} \mathbf{F W})\end{array}$} & \multicolumn{2}{|c|}{$\begin{array}{c}\text { Carotenoids } \\
\text { (mg/g FW) }\end{array}$} & \multicolumn{2}{|c|}{$\begin{array}{c}\mathrm{H}_{2} \mathrm{O}_{2} \\
\text { (nmol. g FW) }\end{array}$} \\
\hline & $\begin{array}{c}1^{\text {st }} \\
\text { season }\end{array}$ & $\begin{array}{c}2^{\text {nd }} \\
\text { season }\end{array}$ & $\begin{array}{c}1^{\text {st }} \\
\text { season }\end{array}$ & $\begin{array}{c}2^{\text {nd }} \\
\text { season }\end{array}$ & $\begin{array}{c}1^{\text {st }} \\
\text { season }\end{array}$ & $\begin{array}{c}2^{\text {nd }} \\
\text { season }\end{array}$ & $\begin{array}{c}1^{\text {st }} \\
\text { season }\end{array}$ & $\begin{array}{c}2^{\text {nd }} \\
\text { season }\end{array}$ & $\begin{array}{c}1^{\text {st }} \\
\text { season }\end{array}$ & $\begin{array}{c}2^{\text {nd }} \\
\text { season }\end{array}$ \\
\hline Control (spraying with water) & $1.69 \mathrm{~d}$ & $1.88 \mathrm{~d}$ & $0.75 \mathrm{e}$ & $0.83 \mathrm{c}$ & $2.44 \mathrm{~d}$ & $2.71 d$ & $0.651 b$ & $0.753 \mathrm{a}$ & $16.74 \mathrm{a}$ & $18.91 \mathrm{a}$ \\
\hline $\mathrm{H}_{2} \mathrm{O}_{2} 30 \%$ at $(1 \mathrm{mM})$ & $1.92 \mathrm{~cd}$ & $2.03 \mathrm{~d}$ & $0.85 \mathrm{de}$ & $0.94 \mathrm{c}$ & $2.77 \mathrm{~cd}$ & $2.97 \mathrm{~cd}$ & $0.538 \mathrm{~d}$ & $0.517 \mathrm{~d}$ & $9.90 \mathrm{~d}$ & $10.59 d$ \\
\hline Nano $\mathrm{CaCO}_{3}$ at $0.5 \%$ & $2.30 \mathrm{ab}$ & $2.55 b$ & $1.08 \mathrm{ab}$ & $1.30 \mathrm{a}$ & $3.38 \mathrm{ab}$ & $3.85 \mathrm{ab}$ & $0.508 \mathrm{e}$ & $0.564 \mathrm{c}$ & $12.79 \mathrm{c}$ & $14.53 \mathrm{c}$ \\
\hline $\begin{array}{l}\mathrm{H}_{2} \mathrm{O}_{2} 30 \% \text { at }(1 \mathrm{mM})+\text { nano } \mathrm{CaCO}_{3} \\
\text { at } 0.5 \%\end{array}$ & $2.49 \mathrm{a}$ & $2.86 a$ & $1.14 \mathrm{a}$ & $1.27 \mathrm{a}$ & $3.62 \mathrm{a}$ & $4.12 \mathrm{a}$ & $0.582 \mathrm{c}$ & $0.646 \mathrm{~b}$ & $7.79 \mathrm{e}$ & $8.98 \mathrm{~d}$ \\
\hline $\mathrm{KCl}$ at $0.5 \%$ & $2.18 \mathrm{a}-\mathrm{c}$ & $2.42 \mathrm{bc}$ & $0.98 \mathrm{bc}$ & $1.19 \mathrm{ab}$ & $3.16 \mathrm{abc}$ & $3.61 \mathrm{a}-\mathrm{c}$ & $0.586 \mathrm{c}$ & $0.650 \mathrm{~b}$ & $13.95 \mathrm{~b}$ & $15.81 \mathrm{bc}$ \\
\hline $\begin{array}{l}\text { Fungicide Tilt } 25 \% \text { EC at } \\
25 \mathrm{~mL} / 100 \text { liter }\end{array}$ & $2.04 b-d$ & $2.26 \mathrm{c}$ & $0.90 \mathrm{~cd}$ & $1.00 \mathrm{bc}$ & $2.94 \mathrm{bc}$ & $3.26 \mathrm{~b}-\mathrm{d}$ & $0.699 \mathrm{a}$ & $0.786 \mathrm{a}$ & $14.79 \mathrm{~b}$ & $16.75 b$ \\
\hline $\mathbf{L S D}_{0.05}$ & 0.36 & 0.19 & 0.10 & 0.22 & 0.46 & 0.83 & 0.028 & 0.034 & 1.01 & 1.87 \\
\hline
\end{tabular}

$1^{\text {st }}$ season $=2019 / 2020,2^{\text {nd }}$ season $=2020 / 2021$ season

Egypt. J. Agron. 43, No. 2 (2021) 
TABLE 5. Effect of treatments on wheat yield components during 2019/2020 and 2020/2021growing seasons

\begin{tabular}{|c|c|c|c|c|c|c|c|c|c|c|}
\hline \multirow[t]{2}{*}{ Treatment } & \multicolumn{2}{|c|}{$\begin{array}{l}1000 \text { kernel } \\
\text { weight }(g)\end{array}$} & \multicolumn{2}{|c|}{$\begin{array}{l}\text { Grain yield (ton } \\
\text { /fed.) }\end{array}$} & \multicolumn{2}{|c|}{$\begin{array}{l}\text { Straw yield } \\
\text { (ton/fed.) }\end{array}$} & \multicolumn{2}{|c|}{$\begin{array}{l}\text { Biological yield } \\
\text { (ton/fed.) }\end{array}$} & \multicolumn{2}{|c|}{$\begin{array}{c}\text { Relative } \\
\text { increases in } \\
\text { grain yield (\%) }\end{array}$} \\
\hline & $\begin{array}{c}1^{\text {st }} \\
\text { season }\end{array}$ & $\begin{array}{c}2^{\text {nd }} \\
\text { season }\end{array}$ & $\begin{array}{c}1^{\text {st }} \\
\text { season }\end{array}$ & $\begin{array}{c}2^{\text {nd }} \\
\text { season }\end{array}$ & $\begin{array}{c}1^{\text {st }} \\
\text { season }\end{array}$ & $\begin{array}{c}2^{\text {nd }} \\
\text { season }\end{array}$ & $\begin{array}{c}1^{\text {st }} \\
\text { season }\end{array}$ & $\begin{array}{c}2^{\text {nd }} \\
\text { season }\end{array}$ & $\begin{array}{c}1^{\text {st }} \\
\text { season }\end{array}$ & $\begin{array}{c}2^{\text {nd }} \\
\text { season }\end{array}$ \\
\hline Control (spraying with water) & $51.89 \mathrm{e}$ & $57.60 \mathrm{e}$ & $1.672 \mathrm{e}$ & $1.789 \mathrm{e}$ & $3.560 \mathrm{e}$ & $3.698 \mathrm{~d}$ & $5.232 \mathrm{e}$ & $5.487 \mathrm{e}$ & 0.00 & 0.00 \\
\hline $\mathrm{H}_{2} \mathrm{O}_{2} 30 \%$ at $(1 \mathrm{mM})$ & $56.53 \mathrm{~d}$ & $62.75 \mathrm{~d}$ & $1.869 \mathrm{~d}$ & $2.091 \mathrm{~d}$ & $3.789 \mathrm{~d}$ & $3.832 \mathrm{~d}$ & $5.658 \mathrm{~d}$ & $5.923 \mathrm{~d}$ & 11.78 & 16.88 \\
\hline Nano $\mathrm{CaCO}_{3}$ at $0.5 \%$ & $61.21 \mathrm{ab}$ & $67.94 b$ & $2.309 \mathrm{ab}$ & $2.563 \mathrm{ab}$ & $4.442 b$ & $5.133 \mathrm{a}$ & $6.751 \mathrm{~b}$ & $7.696 \mathrm{a}$ & 38.09 & 43.26 \\
\hline $\begin{array}{l}\mathrm{H}_{2} \mathrm{O}_{2} 30 \% \text { at }(1 \mathrm{mM})+\text { nano } \\
\mathrm{CaCO}_{3} \text { at } 0.5 \%\end{array}$ & $63.30 \mathrm{a}$ & $70.26 \mathrm{a}$ & $2.444 a$ & $2.602 \mathrm{a}$ & $4.873 \mathrm{a}$ & $5.165 \mathrm{a}$ & $7.317 \mathrm{a}$ & $7.767 \mathrm{a}$ & 46.17 & 45.44 \\
\hline $\mathrm{KCl}$ at $0.5 \%$ & $59.00 \mathrm{bc}$ & $64.44 \mathrm{~cd}$ & $2.294 b$ & $2.491 \mathrm{~b}$ & $4.617 \mathrm{~b}$ & $4.902 b$ & $6.911 b$ & $7.393 b$ & 37.20 & 39.23 \\
\hline $\begin{array}{l}\text { Fungicide Tilt } 25 \% \text { EC at } \\
25 \mathrm{~mL} / 100 \text { liter }\end{array}$ & $58.05 \mathrm{~cd}$ & $65.49 \mathrm{c}$ & $2.044 c$ & $2.346 \mathrm{c}$ & $4.136 \mathrm{c}$ & $4.406 \mathrm{c}$ & $6.180 \mathrm{c}$ & $6.752 \mathrm{c}$ & 22.24 & 31.13 \\
\hline LSD $_{0.05}$ & 2.45 & 2.04 & 0.148 & 0.108 & 0.222 & 0.141 & 0.371 & 0.291 & -- & -- \\
\hline
\end{tabular}

$1^{\text {st }}$ Season $=2019 / 2020,2^{\text {nd }}$ season $=2020 / 2021$ season

The simulative effect of spraying with $\mathrm{H}_{2} \mathrm{O}_{2}$ $30 \%$ at $1 \mathrm{mM}+$ nano $\mathrm{CaCO}_{3}$ at $0.5 \%$ on yield components may be due to the reduction of yellow rust severity $(20.00$ and 22.40$)$ and leaf rust severity (30.00 and 30.60) in the 2019/2020 and 2020/2021 growing seasons, respectively as shown in Table 2. Also, this treatment increased plant growth (Table 3). Nano $\mathrm{CaCO}_{3}$ natural $\mathrm{CO}_{2}$ foliar spray is a new nano-technological fine powdered created by tribodynamic activation and micronization. Nano $\mathrm{CaCO}_{3}$ particles, sprayed finely onto the leaf surface, are taken up directly through the stomata and converted into carbon dioxide. It this way nano $\mathrm{CaCO}_{3}$ can considerably increase the photosynthesis average, since the essential factor limiting photosynthesis, leading to yield increment (Farouk, 2015). In this regard, the superiority of the use of nanoparticles on the total yield and its components can be attributed to its role as a source of calcium and carbonate that reduced inside the plant cell to form carbon dioxide that accumulates in cells and increases the rate of photosynthesis and thus increase vegetative growth and productive yield.

These results are in line with those obtained with Gomaa et al. (2018) on wheat. All they indicated that spraying of wheat plants with nano $\mathrm{CaCO}_{3}$ significantly enhanced all parameter of yield and its components, such as 1000 kernel weight, grain yield and straw yield, as well as biological yield as compared to unsprayed plants. Concerning the response of plants to spraying with $\mathrm{H}_{2} \mathrm{O}_{2}$, Farooq et al. (2017) on wheat, Mogazy et al. (2020) on lupine plants, Ishibashi et al. (2021) on soybean and Jira-anunkul \& Pattanagul (2021) on rice, who showed that spraying plants with low concentration of $\mathrm{H}_{2} \mathrm{O}_{2}$ gave the best results for increasing the components of yield than unsprayed plants. Also, Gad et al. (2020) revealed that minimum disease severity of $1.67 \%$ was recorded with Tilt. This treatment gave a disease control of $98.07 \%$, thus increasing the grain yield and 1000 kernel weight by 29.92 and $73.61 \%$, respectively. It was followed by a disease control of $96.91 \%$ achieved with Crwan $25 \%$ EC which gave an increase of 24.39 and $69.34 \%$ in grain yield and kernel weight, respectively. The analysis of total protein and carbohydrates in grains and straw samples of treated plants showed significant differences within all treatments.

Effect of treatments on mineral content in straw

Spraying plants with water gave the least values of $\mathrm{N}, \mathrm{P}, \mathrm{K}$ and $\mathrm{Ca}$ in straw compared to other spraying treatments (Table 6). Foliar spraying with $\mathrm{H}_{2} \mathrm{O}_{2} 30 \%$ at $1 \mathrm{mM}+$ nano $\mathrm{CaCO}_{3}$ at $0.5 \%$ increased $\mathrm{N}, \mathrm{P}, \mathrm{K}$ and $\mathrm{Ca}$ in straw with no significant differences with spraying with 
$\mathrm{KCl}$ at $0.5 \%$ with respect to $\mathrm{P}$ and $\mathrm{K}$ contents in both seasons. These results are in line with those obtained by El Shazly \& Abd El All (2019) who showed that spraying of cotton plants with nano $\mathrm{CaCO}_{3}$ at $2.5 \mathrm{~g} / \mathrm{L}$ significantly increased $\mathrm{N}, \mathrm{P}$ and $\mathrm{K}$ contents in leaves than unsprayed plants. As for, the effect of $\mathrm{KCl}$ as foliar spray, Khan et al. (2006) who found that spraying of wheat plants with $\mathrm{KCl}$ at $0.5 \%$ had significantly increased $\mathrm{N}, \mathrm{P}$ and $\mathrm{K}$ contents in leaves of wheat than unsprayed plants.

Effect of treatments on mineral content in grains

Foliar spray with the mixture of $\mathrm{H}_{2} \mathrm{O}_{2} 30 \%$ at $1 \mathrm{mM}+$ nano $\mathrm{CaCO}_{3}$ at $0.5 \%$ significantly increased $\mathrm{N}, \mathrm{P}, \mathrm{K}$ and $\mathrm{Ca}$ content in grains with no significant differences with spraying with $\mathrm{KCl}$ at $0.5 \%$ with respect to $\mathrm{P}$ and $\mathrm{K}$ contents in both seasons (Table 6).

\section{Effect of treatments on $N, P$ and $K$ uptake in straw}

Foliar spray with $\mathrm{H}_{2} \mathrm{O}_{2} 30 \%$ at $1 \mathrm{mM}+$ nano $\mathrm{CaCO}_{3}$ at $0.5 \%$ significantly increased $\mathrm{N}, \mathrm{P}$ and $\mathrm{K}$ uptake by straw without significant differences with spraying with $\mathrm{KCl}$ at $0.5 \%$ with respect to $\mathrm{P}$ and $\mathrm{K}$ contents in both seasons (Table 7). Spraying with water (control treatment) recorded minimum values of all three mineral uptakes by wheat straw in both seasons.

\section{Effect of treatments on $N, P$ and $K$ uptake in grains}

All foliar spray treatments had significantly increased $\mathrm{N}, \mathrm{P}$ and $\mathrm{K}$ uptake in grain than spraying with water in both seasons (Table 7). Spraying wheat plants twice after 70 and 100 days from sowing with $\mathrm{H}_{2} \mathrm{O}_{2} 30 \%$ at $1 \mathrm{mM}+$ nano $\mathrm{CaCO}_{3}$ at $0.5 \%$ recorded the maximum values of $\mathrm{N}, \mathrm{P}$ and $\mathrm{K}$ uptake in grains, without significant differences with $\mathrm{KCl}$ at $0.5 \%$ with respect to $\mathrm{P}$ and $\mathrm{K}$ uptake in $1^{\text {st }}$ season and $\mathrm{P}$ uptake in the $2^{\text {nd }}$ season. Foliar spray of potassium significantly increased the uptake of $\mathrm{K}$ in grain, which is due to the penetration of $\mathrm{K}$ into leaves and serves a vital role in photosynthesis to accumulate more $\mathrm{K}$ in grain (Finck, 1982).

\section{Effect of treatments on N, P and $K$ total uptake in plant and total protein in grains}

Spraying of wheat plants with $\mathrm{H}_{2} \mathrm{O}_{2} \quad 30 \%$ at $1 \mathrm{mM}+$ nano $\mathrm{CaCO}_{3}$ at $0.5 \%$ significantly increased $\mathrm{N}, \mathrm{P}$ uptake by wheat plants and total protein in grains in both season without significant differences with nano $\mathrm{CaCO}_{3}$ at $0.5 \%$ and $\mathrm{KCl}$ regarding $\mathrm{P}$ uptake in both seasons (Table 8). As for K total uptake by wheat plants, spraying with $\mathrm{KCl}$ at $0.5 \%$ increased $\mathrm{K}$ total uptake by plants in both seasons. Spraying with water recorded minimum values of $\mathrm{N}, \mathrm{P}$ and $\mathrm{K}$ total uptake by plants as well as total protein in grains in both seasons.

The increases in total protein in grains of wheat were about 40.2 and $32.2 \%$ for spraying with the mixture of $\mathrm{H}_{2} \mathrm{O}_{2} 30 \%$ at $1 \mathrm{mM}$ + nano $\mathrm{CaCO}_{3}$ at $0.5 \%, 29.1$ and $21.1 \%$ for spraying with nano $\mathrm{CaCO}_{3}$ at $0.5 \%$ and 18.0 and 30.3 for spraying with $\mathrm{KCl}$ at $0.5 \%, 12.0$ and $24.0 \%$ for spraying with Tilt fungicide over control treatment in the $1^{\text {st }}$ and $2^{\text {nd }}$ seasons, respectively.

The obtained results show that the foliar application of potassium was effective in improving the quality of the kernels by increasing the grain size and the application of Tilt, which had a positive role in improving the quality of the seed by reducing the black point kernel. Also, the foliar spray of potassium significantly increased the uptake of $\mathrm{K}$ by grain, which is due to the penetration of $\mathrm{K}$ into leaves and serves a vital role. It was clear from previous studies done by Khan et al. (2006), who explained that spraying of wheat plants with $\mathrm{KCl}$ at $0.5 \%$ significantly increased $\mathrm{N}, \mathrm{P}$ and $\mathrm{K}$ uptake by wheat than unsprayed plants; also, Babu et al. (2018) showed that potassium uptake by different rice organs significantly influenced by foliar application of potassium than unsprayed plants.

\section{Conclusion}

From these results it is concluded that the use of hydrogen peroxide $30 \%$ at $1 \mathrm{mM}+$ nano $\mathrm{CaCO}_{3}$ at $0.5 \%$ and $\mathrm{KCl}$ at $0.5 \%$ had a significant effect on controlling wheat rusts and increasing yield with improve grain quality. Using of nano-fertilizers have valuable properties for crops that release nutrient requirements and discharging chemical fertilizers in a controlled manner that standardizes plant growth, improves target activity and also play an important role in decreasing disease severity that seems to be a best alternative to chemical fungicides that resulted in environmental pollution and ill health to biotic community as a whole and for that it plays an important role in food security. 

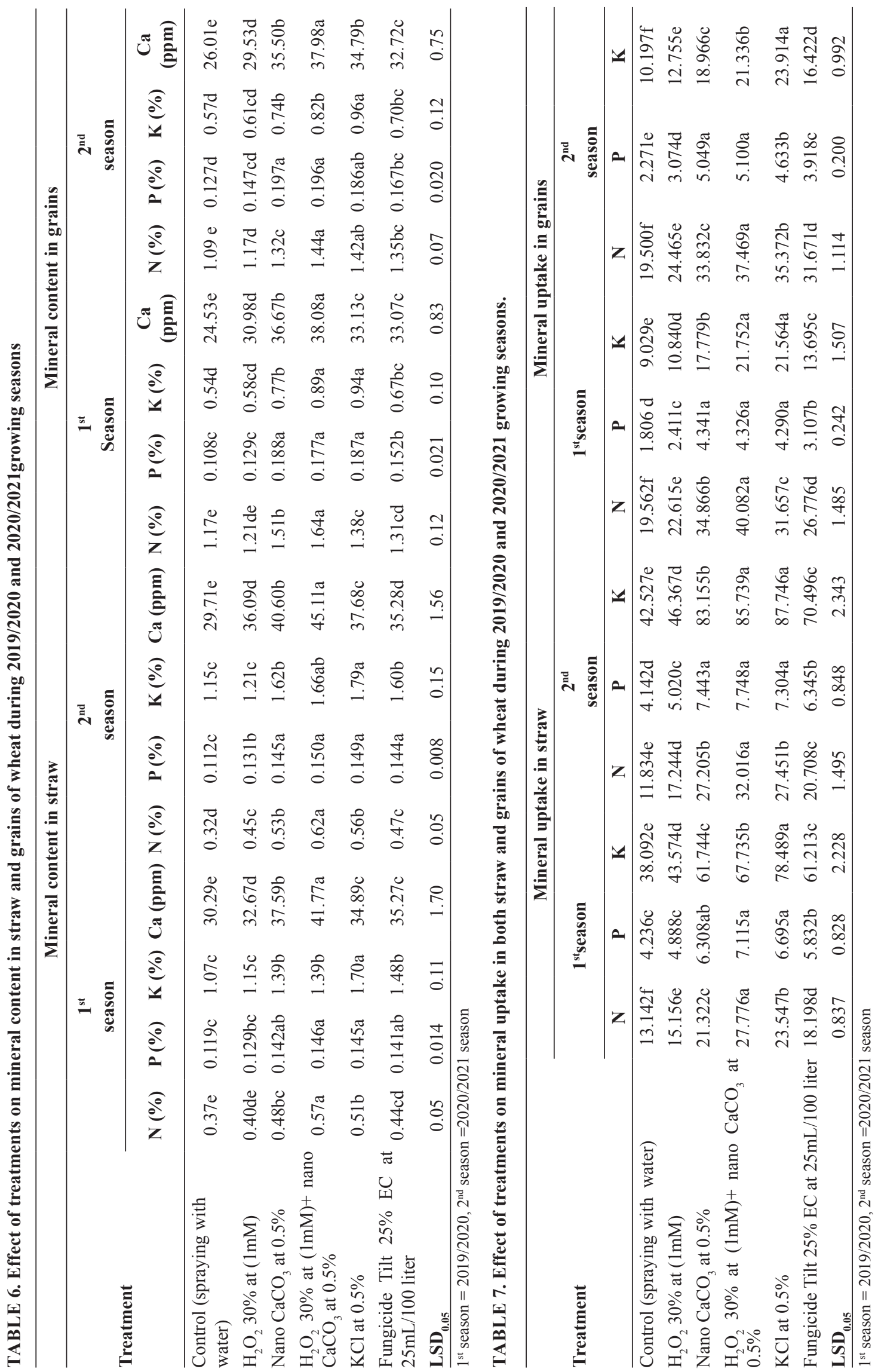

Egypt. J. Agron. 43, No. 2 (2021) 
TABLE 8. Effect of treatments on mineral total uptake and total protein in grains of wheat during $2019 / 2020$ and 2020/2021growing seasons

\begin{tabular}{|c|c|c|c|c|c|c|c|c|}
\hline \multirow{3}{*}{ Treatment } & \multicolumn{6}{|c|}{ Total uptake (kg/Fed.) } & \multirow{2}{*}{\multicolumn{2}{|c|}{$\begin{array}{l}\text { Total protein in } \\
\text { grains }(\%)\end{array}$}} \\
\hline & \multicolumn{2}{|c|}{$\mathbf{N}$} & \multicolumn{2}{|c|}{$\mathbf{P}$} & \multicolumn{2}{|c|}{$\mathbf{K}$} & & \\
\hline & $\begin{array}{c}1^{\text {st }} \\
\text { season }\end{array}$ & $\begin{array}{c}2^{\text {nd }} \\
\text { season }\end{array}$ & $\begin{array}{c}1^{\text {st }} \\
\text { season }\end{array}$ & $\begin{array}{c}2^{\text {nd }} \\
\text { season }\end{array}$ & $\begin{array}{c}1^{\text {st }} \\
\text { season }\end{array}$ & $\begin{array}{c}2^{\text {nd }} \\
\text { season }\end{array}$ & $\begin{array}{c}1^{\text {st }} \\
\text { season }\end{array}$ & $\begin{array}{c}2^{\text {nd }} \\
\text { season }\end{array}$ \\
\hline Control (spraying with water) & $32.734 \mathrm{e}$ & $31.334 \mathrm{f}$ & $6.042 \mathrm{~d}$ & $6.414 d$ & $47.12 \mathrm{f}$ & $52.72 \mathrm{f}$ & $6.67 d$ & $6.21 \mathrm{c}$ \\
\hline $\mathrm{H}_{2} \mathrm{O}_{2} 30 \%$ at $(1 \mathrm{mM})$ & $37.771 \mathrm{~d}$ & $41.709 \mathrm{e}$ & $7.299 \mathrm{c}$ & $8.094 \mathrm{c}$ & $54.41 \mathrm{e}$ & $59.12 \mathrm{e}$ & $6.90 \mathrm{~cd}$ & $6.67 \mathrm{c}$ \\
\hline Nano $\mathrm{CaCO}_{3}$ at $0.5 \%$ & $56.188 b$ & $61.037 \mathrm{c}$ & $10.649 \mathrm{a}$ & $12.492 \mathrm{a}$ & $79.52 \mathrm{c}$ & $102.12 \mathrm{c}$ & $8.61 \mathrm{ab}$ & $7.52 b$ \\
\hline $\begin{array}{l}\mathrm{H}_{2} \mathrm{O}_{2} 30 \% \text { at }(1 \mathrm{mM})+\text { nano } \mathrm{CaCO}_{3} \\
\text { at } 0.5 \%\end{array}$ & $67.858 \mathrm{a}$ & $69.492 \mathrm{a}$ & $11.441 \mathrm{a}$ & $12.848 \mathrm{a}$ & $89.49 b$ & $107.08 b$ & $9.35 \mathrm{a}$ & $8.21 \mathrm{a}$ \\
\hline $\mathrm{KCl}$ at $0.5 \%$ & $54.871 \mathrm{~b}$ & $62.823 b$ & $10.985 \mathrm{a}$ & $11.937 \mathrm{a}$ & $100.05 \mathrm{a}$ & $111.66 \mathrm{a}$ & $7.87 \mathrm{bc}$ & $8.09 \mathrm{a}$ \\
\hline $\begin{array}{l}\text { Fungicide Tilt } 25 \% \text { EC at } \\
25 \mathrm{~mL} / 100 \text { liter }\end{array}$ & $44.974 c$ & $52.379 d$ & $8.939 b$ & $10.263 b$ & $74.91 d$ & $86.92 d$ & $7.47 \mathrm{~cd}$ & $7.70 \mathrm{ab}$ \\
\hline $\mathbf{L S D}_{0.05}$ & 2.019 & 1.456 & 1.070 & 1.050 & 3.278 & 3.804 & 1.00 & 0.51 \\
\hline
\end{tabular}

$1^{\text {st }}$ season $=2019 / 2020,2^{\text {nd }}$ season $=2020 / 2021$ season

\section{References}

A.O.A.C. (2000) Association of Official Agricultural Chemists. "Official Methods of Analysis". 20"thed. A.O.A.C., washingten, D.C.

Adhikari, B., Dhungana, S.K., Kim, D., Shin, D.H. (2020) Effect of foliar application of potassium fertilizers on soybean plants under salinity stress. Journal of the Saudi Society of Agricultural Sciences, 19, 261-269.

Babu, A.P., Hattab, O.K., Aruna, L., Mohan, R. (2018) Effect of sources, split and foliar application of $\mathrm{KCl}$ and $\mathrm{KClO}_{3}$ on uptake of potassium in aerobic rice. Journal of Pharmacognosy and Phytochemistry, 7(4), 1954-1957.

Bishni, U.R., Hughes, I.L. (1979) Agronomic performance and protein content of fall-planted tritica, wheat and rye. Agronomy Journal, 71, 359360 .

Chen, X.M. (2005) Epidemiology and control of stripe rust (Puccinia striformis $\mathrm{f}$ sp. tritici) on wheat. Canadian Journal of Plant Pathology, 27, 314-337.

Cheng, K.L., Bray, R.H. (1953) Two specific methods for determining copper in soil and in plant material. Analytical Chemistry, 25, 655-659.

Deng, X.P., Cheng Y.J., Wu, X.B. (2012) Exogenous hydrogen peroxide positively influences root growth and exogenous hydrogen peroxide positively influences root growth and metabolism in leaves of sweet potato seedlings. Australian Journal of Crop Science, 6,1572-1578.

El Shazly, M.W., Abd El All, A.M. (2019) Response of Giza 86 cotton cultivar to foliar feeding with lithovit and boron. International Journal of Advanced Research in Biological Sciences, 6(1), 33-49.

El-Naggar, D.R., El-Orabey, W.M., Gad, M.A., Hermas, G.A. (2020) Characterisation of virulence and diversity of Puccinia graminis f. sp. tritici on wheat in Egypt. Egyptian Journal of Agronomy, 42(1), 1933.

El-Orabey, W.M., Hamwieh, Al., Gad, M.A., Ahmed, Shaimaa M. (2019) Virulence and Molecular Polymorphism of Puccinia triticina pathotypes in Egypt. International Journal of Phytopathology, 08(03), 111-122.

El-Orabey, W.M., Mabrouk, O.I., Gad, M.A., Esmail, S.M. (2020) Inheritance and detection of leaf rust resistance genes in some Egyptian wheat cultivars. International Journal of Genetics and Genomics, 8(1), 1-10.

Farooq, M., Nawaz, A., Chaudhary, M.A.M., Rehman A. (2017) Foliage-applied sodium nitroprusside and hydrogen peroxide improves resistance against terminal drought in bread wheat. Journal of Agronomy and Crop Science, 203, 473-482.

Farooqut, A., Tabassum, H., Ahmad, A., Mabood, A., Ahmad, A., Ahmad, I.Z. (2016) Role of nanoparticles in growth and development of plants:

Egypt. J. Agron. 43, No. 2 (2021) 
A Review. International Journal of Pharma and Bio Sciences, 7(4), 22-37.

Farouk, S. (2015) Improving growth and productivity of potato (Solanum tuberosum L.) by some biostimulants and lithovit with or without boron. Journal of Plant Production, Mansoura University, 6(12), 2187-2206.

Finck, A. (1982) "Fertilizers and Fertilization". Verlag Chimie GmbH, Wein heim, Germany.

Gad A.M., Abdel-Halim, Kh.Y., Seddik, F.A., Soliman, H.M.A. (2020) Comparative of fungicidal efficacy against yellow rust disease in wheat plants in compatibility with some biochemical alterations. Menoufia Journal of Plant Protection, 5, 29-38.

Gad, M.A., Li, H., Alama, Md.A., Sajjad M., Li, M. (2019a) Geographical distribution and virulence phenotypes of Puccinia striiformis f. sp. tritici from wheat in Yunnan, China. Science Asia, 45, 572-580.

Gad, M.A., Li, H., Li, M., El-Orabey, W.M., Hasan, M.A. (2019b) Evaluation of wheat genotypes to rust diseases (Puccinia spp.) under agroclimatic conditions of Egypt and China. Journal of Agricultural and Crop Research, 7(9), 170-180.

Gebrel, E.E., Gad, M.A., Farouk, M. (2020) Study of some crop and technological characteristics of some wheat cultivars under different levels of nitrogen fertilization and their affected by rust diseases. Journal of Plant Production, Mansoura University, 11(10), 1021-1030.

Gebrel, E.E., Gad, M.A., Farouk, M. (2019) Response of some wheat cultivars to different nitrogen fertilizer rates and their Rrelation to rust diseases. Egyptian Journal of Agronomy, 41(3), 243-254.

Gebril, E.E., Gad, M.A., Kishk, A.M.S. (2018a) Effect of sowing dates on potential yield and rust resistance of some wheat cultivars. Journal of Plant Production, Mansoura University, 9(4), 369-375.

Gebril, E.E.M.A., Gad, M.A., Rashwan, E.A. (2018b) Genetic divergence and its relation to yield and rust disease resistance of some bread wheat crosses under different nitrogen fertilizer levels. Egyptian Journal of Plant Breeding, 22(7), 1591-1615.

Gomaa, M.A., Radwan, F.I., Kandil, E.E., Al-Masri, M.A.F. (2018) Response of some Egyptian and Iraqi wheat cultivars to mineral and nano-fertilization. Egyptian Academic Journal of Biological Sciences, 9(1), 19-26.

Hasan, M.A., Boult, O.A., Abou-Zeid, M., Gad, M.A. (2016) Impact of different levels of stem and stripe rust severities on two grain yield components of wheat. Menoufia Journal of Agriculture Research, 41(3), 621-629.

Ishibashi, Y., Yamaguchi, H., Yuasa, T., Inoue, M. (2021) Hydrogen peroxide spraying alleviates drought stress in soybean plants. Journal of Plant Physiology, 168(13), 1562-1567.

Jira-anunkul, W., Pattanagul, W. (2021) Effects of hydrogen peroxide application on agronomic traits of rice (Oryza sativa L.) under drought stress. Plant, Soil and Environment, 67(4), 221-229.

Khan, M.Z., Muhammad, S., Naeem, M.A., Akhtar, E., Khalid, M. (2006) Response of some wheat (Triticum aestivum $L$.) varieties to foliar application of $\mathrm{N}$ and $\mathrm{K}$ under rainfed conditions. Pakistan Journal of Botany, 38(4),1027-1034.

Kumar, P. (2011) Nanotechnology in Agriculture. Financing agriculture Journal, Bombay: Agricultural Finance Corp. Ltd., 34, 8-10.

Mengel, K., Kirkby, E.A. (2001) "Principles of Plant Nutrition". $5^{\text {th }}$ ed., Kluwer Academic Publishers, Dordrecht.

Mogazy, A.M.; Seleem, E.A., Mohamed, G.F. (2020) Mitigating the harmful effects of water deficiency stress on white lupine (Lupinus albus L.) plants by using Algae extract and hydrogen Peroxide. Journal of Plant Production, Mansoura University, 11(10), 921-931.,

Neumann, S., Paveley, N.D., Beed, F.D., SylvesterBradley, R. (2004) Nitrogen per unit leaf area affects the upper asymptote of Puccinia striiformis f. sp. tritici epidemics in winter wheat. Plant Pathology, 53, 725-732.

Omara, R.I., Abdelaal, Kh.A.A. (2018) Biochemical, histopathological and genetic analysis associated with leaf rust infection in wheat plants (Triticum aestivum L.). Physiological and Molecular Plant Pathology, 104, 48-57.

Page, A.L. (1982) "Methods of Soil Analysis. Chemical 
and Microbiological Properties". $2^{\text {nd }}$ ed., Agron. 9, Am. Soc. Agron. Inc. Publ. Madison, Wis, USA.

Peterson, R.F., Campbell, A.B., Hannah, A.E. (1948) A diagrammatic scale for rust intensity on leaves and stems of cereals. Canadian Journal of Research, 26, 496-500.

Rahman, M.A.; Rahman, M.M., Hasan, M.M., Begum, F., Sarker, M.A.Z. (2014) Effects of foliar application of potassium orthophosphate on grain yield and kernel quality of wheat (Triticum aestivum) under terminal heat stress. Bangladesh Journal of Agricultural Research, 39(1), 67-77.

Ransom, J.K., McMullen, M.P. (2008) Yield and disease control on hard winter wheat cultivars with foliar fungicides. Agronomy Journal, 100(4), 11301137.

Rebbeck, J., Scherzer, A.J. (2002) Growth responses of yellow poplar (Liriodendron tulipifera L.) exposed to 5 years of $\mathrm{O}_{2}$ alone or combined with elevated $\mathrm{CO}_{2}$. Plant, Cell \& Environment, 25, 1527-1537.
Soliman, N.E.K., Abdelbacki, A.M.M., Najeeb, M.A.A., Omara, R.I. (2012) Geographical distribution of physiological races of Puccinia triticina and postulation of resistance genes in new wheat cultivars in Egypt. ESci Journal of Plant Pathology, 1, 73-80.

Tervet, I., Cassel, R.C. (1951) The use of cyclone separation in race identification of cereal rusts. Phytopathology, 41, 282-285.

Velikova, V., Yordanov, I., Edreva, A. (2000) Oxidative stress and some antioxidant systems in acid raintreated bean plants. Plant Science, 151, 59-66.

Wang, K.T., Zheng, Y.H., Tang, W.C., Li, T.J., Zhang, Q., Shang, H.T. (2012) Effects of methyl jasmonate treatment on levels of nitric oxide and hydrogen peroxide and phytoalexin synthesis in postharvest grape berries. Acta Horticulturae Sinica, 39, 15591566.

Wettestein, D. (1957) Chlorophyll-letale und der submikroskopische Formwechsel der Plastiden. Experimental Cell Research, 12, 427-506.

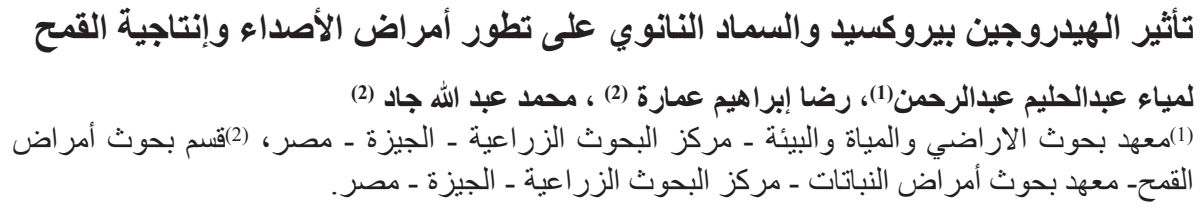

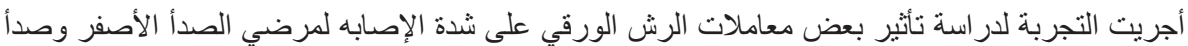

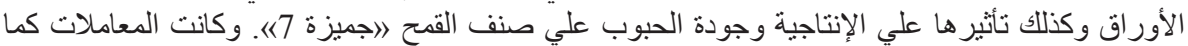
يلي: of $\mathrm{H}_{2} \mathrm{O}_{2} 30 \%(1.0 \mathrm{mM})$, and nano $\mathrm{CaCO}_{3} 0.5 \%(5.0 \mathrm{~g} / \mathrm{L}), \mathrm{KCl}(5.0 \mathrm{~g} / \mathrm{L})$ and fungicide Tilt 25\% EC (Propiconazole) at 25mL/100 liter

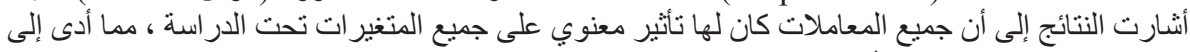

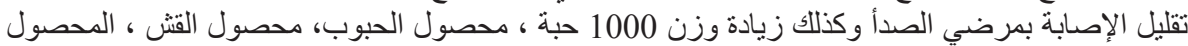

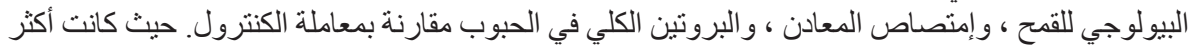

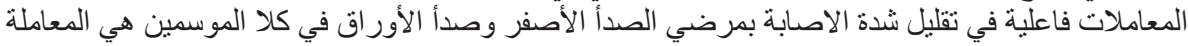

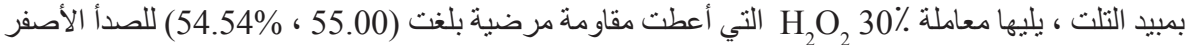

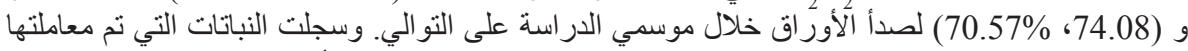
بـ nano CaCO $0.5 \%$ +

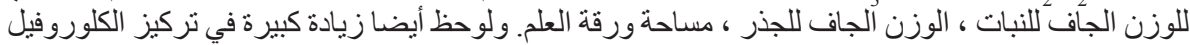

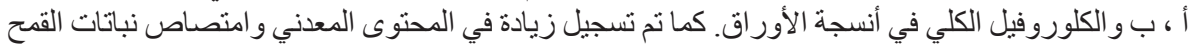

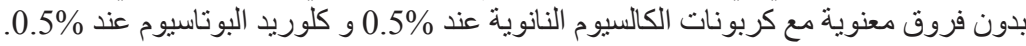

